\title{
Ppe Tube Filled With Autologous Fat in the Repair of Peripheral Nerve: A New Proposal
}

\author{
Tubo Ppe Relleno con Grasa Autóloga en la Reparación \\ de los Nervios Periféricos: Una Nueva Propuesta
}

\begin{abstract}
Gustavo Lopes Toledo*; Juliana Dreyer da Silva de Menezes"*; Juliana de Almeida Nascimento**; Jesus Carlos Andreo***; Rogério Leone Buchaim***; André Luis Shinohara**; Geraldo Marco Rosa Junior**** \& Antonio de Castro Rodrigues ${ }^{* * * *}$
\end{abstract}

TOLEDO, G. L.; DA SILVA DE MENEZES, J. D.; DE ALMEIDA NASCIMENTO, J.; ANDREO, J. C.; BUCHAIM, L. R.; SHINOHARA, A. L.; ROSA JUNIOR, G. M. \& DE CASTRO RODRIGUES, A. Ppe tube filled with autologous fat in the repair of peripheral nerve: a new proposal. Int. J. Morphol., 34(3):1151-1157, 2016.

SUMMARY: This study proposes the use of a porous polyethylene (PPE) tube as the conductive element in the regeneration in the sciatic nerve sectioning and evaluates the use of fill with autologous fat. The subject was divided randomly into five groups, 3 control and 2 experimental (PPE tube graft with/ without autologous fat). Each group was selected for functional, histological and morphometric evaluation of the sciatic nerve. Functional analysis of the sciatic nerve occurred through the "footprint" values near - 100 refer sectioned sciatic nerve, near 0 (zero) refer to control group. On histological analysis of the experimental groups lots of dense connective tissue replacing nerve tissue was observed. In morphometric analysis the group EGPGf got higher performance in all of variables. The use of PPE has shown promise in nerve regeneration with favorable results when associate with fat as a trophic factor in the regeneration.

KEY WORDS: Rat sciatic nerve; Axonal regeneration; Porous polyethylene pipe.

\section{INTRODUCTION}

Considering the types of nerve injuries, the neurotmesis is characterized by complete rupture of the axon and supporting structures, which makes its repair more complex (Grant et al., 1999). Despite microsurgical advances, patients with peripheral nerve injury may experience suboptimal clinical outcomes after treatment (Hart et al., 2008). The success of axonal regeneration is among others dependent on the defect (Bellamkonda, 2006).

In short gaps the primary repair is the most effective technique. However, when loss of nerve tissue occurs resulting in long gaps, more than $3 \mathrm{~cm}$, the graft interposition is a versatile means since it offers both mechanical guidance and accumulation and containment of trophic substances such as cytokines for the out growing axonal sprouts (Hudson et al., 1979; Ferrari et al., 1999; Sundback et al., 2003).
The gold standard treatment is the autologous nerve graft (ANG), used successfully in bridging peripheral nerve defects in clinical practice (Evans, 2001; Meek et al., 2002). However, this method causes donor site morbidity, such as scarring, neuroma formation, and sensory deficits (Evans).

The tubulization technique appears as an alternative to ANG method for bridging peripheral nerve injury. This technique uses tubular guide aiming to provide a favorable microenvironment for regeneration and the addition of cellular components inside the conduit may enhance nerve regeneration (Braga-Silva et al., 2008). In addition to conduit modifications, manipulating the internal environment of nerve conduits has improved nerve regeneration by the supplementation of extracellular matrix molecules, growth factors, Schwann cells and other neurotrophic agents (Sundback et al.).

\footnotetext{
Phd, Associate Professor of Universidade de Marília (UNIMAR) \& Student of Faculdade de Odontologia of Universidade de São Paulo (USP), São Paulo, Brazil.

** Master of Universidade de São Paulo (USP), São Paulo, Brazil.

**** Associate Professor of Faculdade de Odontologia de Bauru of Universidade de São Paulo (FOB-USP), São Paulo, Brazil.

${ }^{* * * *}$ Associate Professor of Universidade do Sagrado Coração (USC), Bauru, São Paulo, Brazil.
} 
Some studies have concentrated on the manipulation of adipose-derived stem cells (ADSCs) for neuroregeneration. Recently, it has been shown that both differentiated and undifferentiated ADSCs promoted peripheral nerve regeneration, and the beneficial effects of ADSCs are comparable to that of bone marrow stromal cells (Santiago et al., 2009; Mohammadi et al., 2011). Despite these promising studies, knowledge concerning the therapeutic use of adipose tissue to promote peripheral nerve regeneration is limited and further studies are required to prove their potential.

One concern about the tubulization of the nerve impermeable conduit is the lack vascularization and trophic support. It is well established that the extent of axonal regeneration through nerve conduits is influenced by the local regenerative milieu and hypoperfusion may lead to ischemia and delayed regeneration (Lundborg et al., 1979). Several authors have addressed this problem and introduced conduits with permeable wall structures. It should provide a mechanically stable tunnel against scar tissue invasion but must allow for nutrient supply to the regenerating nerve (Sunderland, 1985).

This prospective randomized study proposes the use of a manufactured porous polyethylene (PPE) tube as the conductive element in the regeneration of the sciatic nerve sectioning by experiment. For comparative purposes, the regeneration was evaluated in a group which was used in filling with autogenous fat and another group unfilled.

\section{MATERIAL AND METHOD}

All studies were approved by the Institutional Animal Care and Use Committee and conducted in accordance with the NIH Guide for the Care and Use of Laboratory Animals. Thirty-seven rats (Rattus norvegiccus) Wistar, young, male, 60 days old, weighing $250 \mathrm{~g}$ on average, from

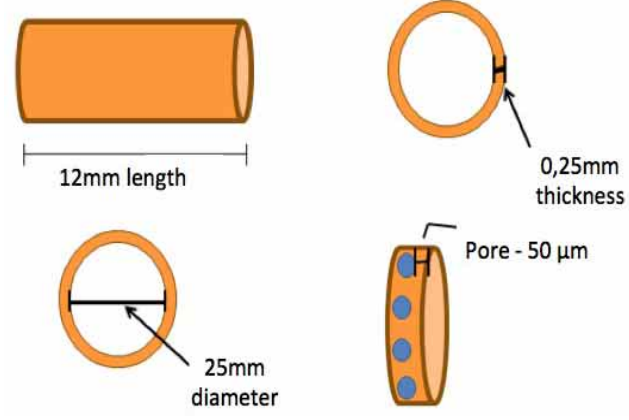

the Vivarium of the Dentistry School of Bauru, University of São Paulo (USP) - Bauru - SP were used in the experiment.

The animals were kept in ventilated plastic boxes arranged in a bookshelf; the temperature was controlled ( 24 ${ }^{\circ} \mathrm{C}$ ) and light-dark cycles lasted $12 \mathrm{~h}$. Food and water were offered ad libitum.

The sample was randomly divided between the four groups, with 7 animals in the control groups and 8 animals in the experimental groups.

Control Group (CG); n=7

Denervated Control Group (DCG); n=7

Experimental Group Polyethylene Graft unfilled (EGPGu); $\mathrm{n}=8$

Experimental Group Polyethylene Graft filled with fat (EGPGf); $\mathrm{n}=8$

Surgical Procedures and Collection of Samples: All surgical procedures and sampling were performed by a single person and aseptic techniques were adopted at all stages. After weighting, the animals underwent general anesthesia by intramuscular injection Zolazepam hydrochloride with tiletamine hydrochloride $50 \mathrm{mg} / \mathrm{ml}$ (Zoletil@ Reading/ Virbac, Carros, France).

Each animal was identified and the right lower limb prepared for the procedure. In groups DCG and CG the animals were placed in the prone position and a longitudinal incision of $2 \mathrm{~cm}$ was performed in the dorsolateral surface of the right thigh. Dissection of tissue planes for exposure and dissection of the sciatic nerve. After a middle segment of the nerve approximately $1.5 \mathrm{~cm}$ length was collected in the Control Group (CG), and the distal stump segment of the sciatic nerve in the Denervated Control Group (DCG) of the same length, the samples were fixed in formaldehyde, glutaraldehyde and Karnovsky, and subsequently embedded in paraffin for histological processing.

Fig. 1. Features of the manufactured porous polyethylene tube. 
In the experimental group (EGPGu), the animals were placed in the prone position and a longitudinal incision of $2 \mathrm{~cm}$ was performed at the dorsal side of the right thigh. Dissection of tissue planes for exposure of the sciatic nerve. A segment measuring about $1 \mathrm{~cm}$ was removed and a manufactured Porous Polyethylene tube was interpositioned. Polyethylene tubes were made with 0.25 $\mathrm{mm}$ thickness, $12 \mathrm{~mm}$ length and $25 \mathrm{~mm}$ in diameter, with pores created with the aid of laser (Fig. 1). The proximal and distal stumps were sutured with 10-0 nylon, no filling material was used. In the EGPGf the same procedure was conducted, however, the tubes were filled with autogenous fat (Figs. 2A, 2B, 2C, 2D).

Sciatic Nerve Functional Assessment: Prior to euthanasia, 3 animals from each group were randomly selected for functional evaluation of the sciatic nerve. Therefore, animals were immobilized, and the plantar region of their hind paws were painted with ink. On a wood surface, a strip of paper was positioned so that the animals walked and left impressions on it. This procedure was repeated twice per animal. The distances between prints of the hind limbs were evaluated according to Bain equation, Mackinon \& Hunter (1989) based in studies by De Medinaceli, Fred \& Wyatt (1982). Impressions difficult to analyze were discarded, and the remaining were scanned and digitized. The measurements were made with the aid of Image Pro-plus, and the data was subjected to statistical index of $t$ student test obeying $\mathrm{P}<0.05$ for all samples.
The sample undergone euthanasia with 150 days of the initial procedure and the sciatic nerves were subjected to histological processing for morphometric analysis to evaluate the efficiency of nerve regeneration in the different groups. Morphometry was performed, measuring 220 fibers from each animal in each group, using a software capture and image analysis Image-Pro Plus 6.0, coupled to the optical microscope Olympus BX-50. The analysis of variance and Tukey's test for comparison between the 4 groups were used, with a significance level of $5 \%(\mathrm{p}<0.05)$.

\section{RESULTS}

Macroscopic analysis: During the surgical procedures, macroscopic dissection of the sciatic nerve were made with the tubing technique. It was not possible to observe changes in the length of the sciatic nerve in the experimental groups compared with the control, however, this difference was visible in the muscles.

Due to the use of non-resorbable material, there was careful removal of the tube, this procedure was carried out with a scalpel blade with the aid of a surgical microscope. In most animals of the experimental groups the formation of dense connective tissue was noted after removal of the supposed regenerated nerve within the tube, it had the form of a hourglass (Figs. 2E, 2F).
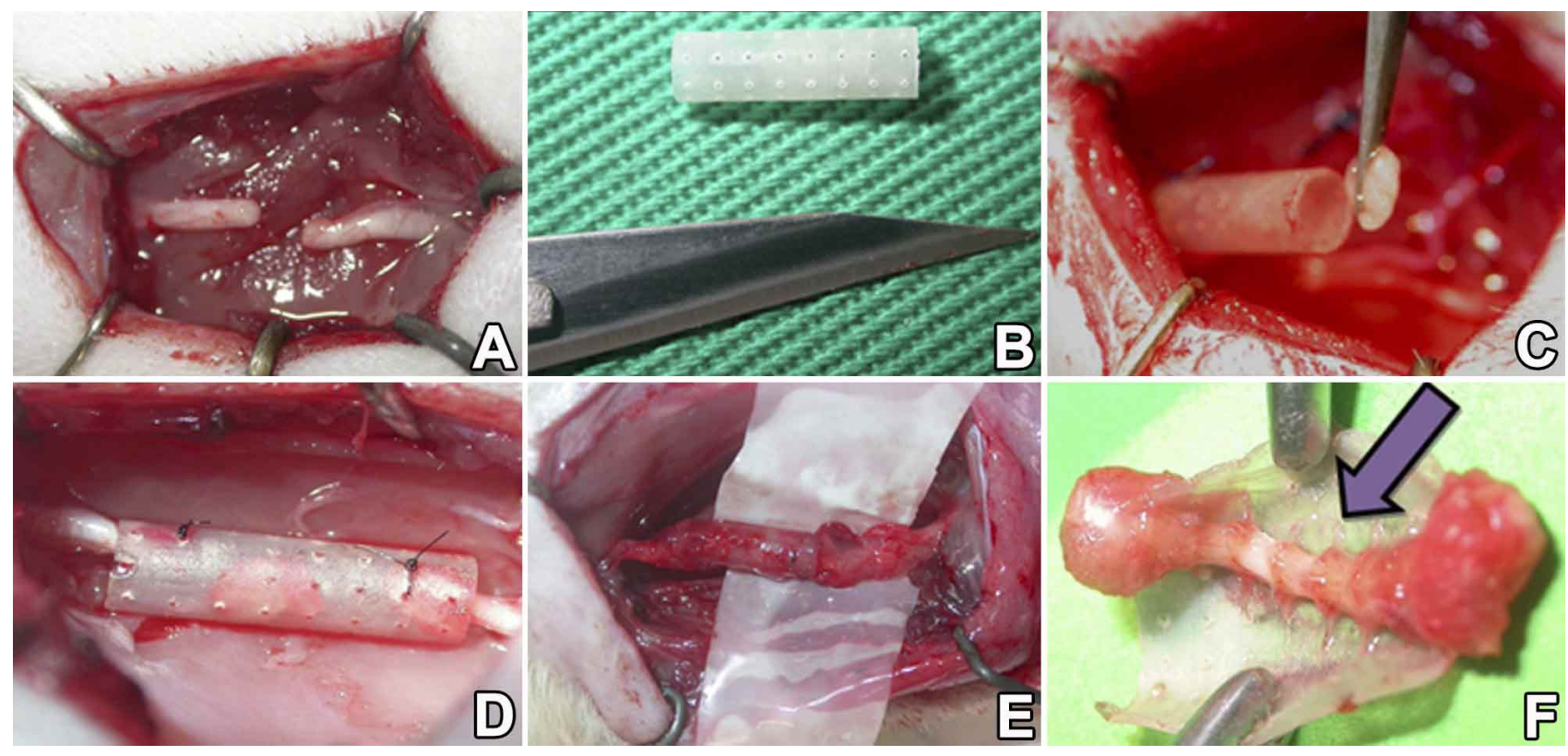

Fig. 2. A. Sciatic nerve section. B. Manufactured Porous Polyethylene tube and scalpel blade used during the procedure. C. Polyethylene tube placement, filled with autologous fat. D. Proximal and distal nerve stumps were sutured to the Polyethylene tube with 10-nylon. E. Formation of dense connective tissue. F. Removal of the tube and display of the supposed nerve regeneration. 
Functional analysis of the sciatic nerve: Functional analysis of the sciatic nerve occurred through the "footprint", values near -100 refer to sectioned sciatic nerve while values near 0 (zero) refer to control group (normal), as shown in Table I.

Table I. Footprint values. Values near 0 (zero) refer to control group (normal).

\begin{tabular}{lll}
\hline Groups & Average & SD \\
\hline CGD $(n=3)$ & -80.97 & 66.43 \\
FCG $(n=3)$ & -0.78 & 14.23 \\
EGPGf $(n=3)$ & -75.59 & 13.76 \\
EGPGu $(n=3)$ & -63.50 & 2.21 \\
\hline
\end{tabular}

The analysis of these variables showed that the values were different, especially when comparing experimental groups to the $\mathrm{CG}$.

Histological Analysis: On histological analysis of the experimental groups lots of dense connective tissue replacing nerve tissue was observed. Moreover, irregularities of nerve fibers, with greater intensity in EGPGu were also noticed. Regenerated nerve cables shown to be composed of myelinated and unmyelinated nerve fibers of heterogeneous diameters (Fig. 3).

Morphometric aspects of nerves: The data were compiled into a framework for comparative purposes in which groups with the same letter showed no statistically significant difference between them (Table II).

Area of the nerve fibers of the sciatic nerve - The experimental group received a statistically significant value compared with the group CG, however, when comparing the experimental groups together, there was no statistically significant values.

Axons Sciatic nerve area - All the results obtained in the experimental groups were statistically different from the values obtained in the control groups, but when compared they did not have the same statistical differences, EGPGf has provided superior value $\left(7.06 \mu \mathrm{m}^{2}\right)$ to EGPGu $\left(5.20 \mu \mathrm{m}^{2}\right)$.
Fiber diameter of sciatic nerve - Experimental groups showed statistically different when compared with the CG. However, when analyzed together, the experimental groups showed no statistical significant values even with values different from each other $(\mathrm{EGPGf}=5.30 \mu \mathrm{m}$ and $\mathrm{EGPGu}=4.69 \mu \mathrm{m})$.

Axon diameter of the Sciatic nerve - The experimental groups showed significant difference when compared to the $\mathrm{CG}$, while when evaluated together they did not represent significant difference even though they have different values $(\mathrm{EGPGf}=2.36 \mu \mathrm{m}$ and $\mathrm{EGPGu}=$ $2.06 \mu \mathrm{m})$.

Area of the myelin sheath of nerve Sciatic - The CG group showed statistically significant results when confronted to experimental groups, which, once analyzed, did not show significant results despite different $(24.40$ $\mathrm{mm}^{2}$ for EGPGf and $17.49 \mathrm{~mm}^{2}$ to EGPGu).

Thickness of the myelin sheath of nerve Sciatic Unlike the others, there were no statistical differences between the CG $(3.48 \mu \mathrm{m})$, EGPGf $(2.94 \mu \mathrm{m})$ and EGPGu (2.63 $\mu \mathrm{m})$.

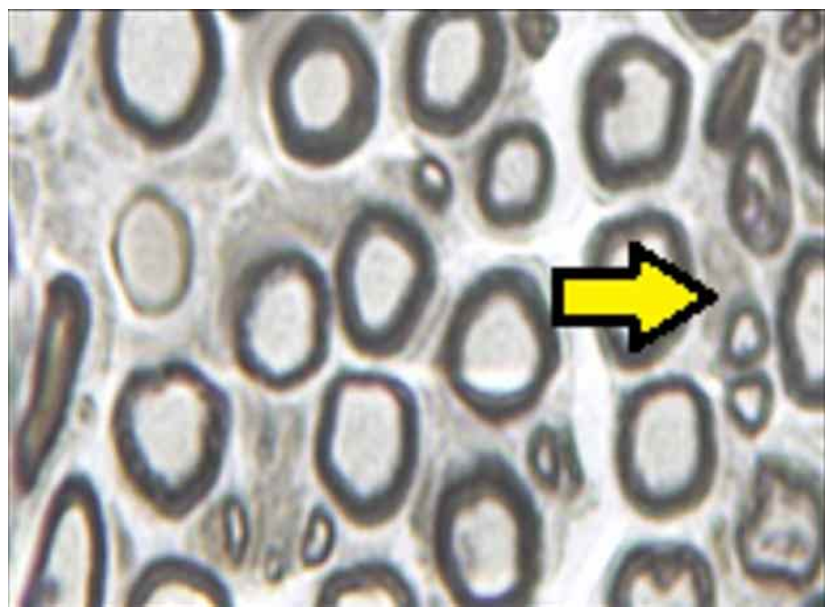

Fig. 3. Histological analysis of the experimental groups. The arrow indicate dense connective tissue replacing nerve tissue.

Table II. Morphometric aspects of the nerves.

\begin{tabular}{|c|c|c|c|c|c|c|c|c|c|c|c|c|}
\hline \multirow[b]{2}{*}{ Groups } & \multicolumn{2}{|c|}{ FA } & \multicolumn{2}{|c|}{$\mathbf{A A}$} & \multicolumn{2}{|c|}{ FD } & \multicolumn{2}{|c|}{ AD } & \multicolumn{2}{|c|}{ AS } & \multicolumn{2}{|c|}{ ST } \\
\hline & Average & SD & Average & SD & Average & SD & Average & SD & Average & SD & Average & SD \\
\hline CGD & 18.64 & 2.29 & 5.40 & 1.52 & 4.42 & 0.41 & 7.48 & 0.18 & 5.30 & 0.77 & 4.69 & 0.22 \\
\hline FCG & 53.11 & 6.48 & 14.71 & 3.77 & 2.19 & 0.77 & 3.93 & 0.8 & 2.36 & 3.38 & 2.03 & 0.47 \\
\hline EGPGf & 30.70 & 6.32 & 7.06 & 0.79 & 13.23 & 0.65 & 38.40 & 0.35 & 24.40 & 5.71 & 17.49 & 0.39 \\
\hline EGPGu & 22.69 & 8.65 & 5.20 & 1.77 & 2.22 & 1 & 3.48 & 0.48 & 2.94 & 7 & 2.63 & 0.6 \\
\hline
\end{tabular}


TOLEDO, G. L.; DA SILVA DE MENEZES, J. D.; DE ALMEIDA NASCIMENTO, J.; ANDREO, J. C.; BUCHAIM, L. R.; SHINOHARA, A. L.; ROSA JUNIOR, G. M. \& DE CASTRO RODRIGUES, A. Ppe tube filled with autologous fat in the repair of peripheral nerve: a new proposal. Int. J. Morphol., 34(3):1151-1157, 2016.

\section{DISCUSSION}

The technical principles of peripheral nerve repairs were based on Waller's observations, in the nineteenth century, about the regeneration of the distal stump and the projections (sprouting) of axons from the proximal stump of the injured nerve. Since then, research centers around the world have developed new techniques of nerve repair with successful results (Lundborg et al.).

The injury of choice for the study of regeneration is neurotmesis, because it is more severe and has difficult recovery (Oliveira et al., 2004). This type of injury occurs when there is significant loss of tissue, and tubing is needed to guide axonal sprouting from proximal to distal stump. The experimental lesions in previous studies ranged from $4 \mathrm{~mm}$ to $25 \mathrm{~mm}$ (Da-Silva et al., 1989). A sample of this study was subjected to lesions of $10 \mathrm{~mm}$.

The use of biological and non-biological materials as conductive elements of regeneration of nerve fibers have been widely studied. Thus, materials such as collagen, arteries, veins, cell adhesion molecules, Polyethylene tubes were proposed (Kakinoki et al., 1997).

The use of synthetic tubes provides a primary frame to guide the migration of fibroblasts, Schwannocytus and eventually axonal projections (Fields et al., 1989). Furthermore, the use of these materials provides less surgical damage because they do not require two surgical sites, an example of what happens with the biological material (Battiston et al., 1990; Kljavin et al., 1991; Barcelos et al., 2003).

Neovascularization in nerve grafts is crucial to the regenerative process. Vessels inside the tubes showed to be beneficial and useful for the repair of peripheral nerves in humans (Da-Silva et al.). New structural pores were then added to the polyethylene pipes to allow nutrition through small capillaries surrounding the graft, thus speeding up the regeneration process (Da-Silva et al.).

Tension on the suture site of nerve graft is harmful to the regenerative process, scar tissue obliterates the light in which the fibers must pass through during regeneration. For this reason the porous polyethylene tube has length of $12 \mathrm{~mm}$, while the injury limited to $5 \mathrm{~mm}$. It is important to mention that after generating an injury retraction occurs naturally, further increasing the gap between the proximal and distal stumps.

With the development of genetic engineering and enhancement of experimental surgery, the use of components with growth factors and stem cells, inside the biological and non-biological tubes, have been increasingly common (Braga-Silva et al.). Fat tissue has been widely used for presenting these characteristics, and for being easily found in the surgical site and easily be removed without aesthetic impairment. One of the experimental porous polyethylene grafted groups received little portions of adipose cells collected in situ (Georgiou et al., 2015).

During the histological analysis of the middle third of the grafts and the middle third of the distal stump of all groups, the presence of myelinated and unmyelinated heterogeneous nerve fibers was observed. The neoformation of perineurium and intraneural organization of fascicles of various sizes that agree with the consulted authors (Ferrari et al.). In addition, regenerating axons were observed in all animals of all the experimental groups. It was suggested that the axons grew from the proximal stump of the sciatic nerve, went through the intersegment space and reached the distal stump of the nerve, because, in all analyzed variables the parameters were higher in the middle third of the graft than the distal stump region.

In morphometric analysis, when comparing variables in the sciatic nerve, it was noted that the group EGPGf got higher performance in all of them. Furthermore, the variable thickness of the myelin sheath was statistically equal to CG, corroborating with other studies (Santiago et al.). Analyzing the results for each variable the presence of autologous adipose tissue was observed, contributing significantly in morphometric results particularly in variables area and thickness of the myelin sheath.

Considering the functional analysis of the studied nerves, we found that although not statistically significant, the group EGPGu showed better results when compared to EGPGf. However, if considering the proportional area development axon to the thickness of the myelin sheath, the index of myelination, the best results were observed in the second mentioned group (Buchaim et al., 2015). Two hypotheses can be credited in this case, number one is that the functional findings presented no significance when comparing the experimental groups, the second one is the irrelevance of the analysis of the air proportion vs thickness ratio, despite having been more successful in the group with adipose tissue.

\section{CONCLUSIONS}

The use of the manufactured porous polyethylene graft has shown promise in nerve regeneration, for 
minimizing the surgical trauma and reducing the surgical approach. Despite presenting semi-rigid consistency polyethylene was shown to have pressure resistance, and no structural collapse was observed. The use of fat as a trophic factor in the regeneration appeared to be favorable when compared with non-use. The morphometric results showed EGPGf group closest to the control group. Certainly, there are more questions than answers for the evaluation of peripheral nerve regeneration. However, special attention should be given to the use of stem cells in tissue regeneration for greater understanding and improvement of the technique.

TOLEDO, G. L.; DA SILVA DE MENEZES, J. D.; DE ALMEIDA NASCIMENTO, J.; ANDREO, J. C.; BUCHAIM, L. R.; SHINOHARA, A. L.; ROSA JUNIOR, G. M. \& DE CASTRO RODRIGUES, A. Tubo Ppe relleno con grasa autóloga en la reparación de los nervios periféricos: Una nueva propuesta. Int. J. Morphol., 34(3):1151-1157, 2016.

RESUMEN: Este estudio propone el uso de un tubo de polietileno poroso (PPE) como elemento conductor en la regeneración del nervio ciático seccionado y evaluar el uso de relleno con grasa autóloga. Al azar se formaron cinco grupos, 3 y 2 de control experimental (PPE prótesis tubular con / sin grasa autóloga). Cada grupo fue seleccionado para estudiar la forma funcional, histológica y evaluación morfométrica del nervio ciático. Un análisis funcional del nervio ciático se produjo a través de los valores de "huella", cerca de -100 se refiere al nervio ciático seccionado; cerca de 0 (cero) se refiere al grupo control. En el análisis histológico de los grupos experimentales se observó una gran cantidad de tejido conjuntivo denso que sustituye el tejido nervioso. En el análisis morfométrico, el grupo experimental de injerto de polietileno lleno de grasa (EGPGf) obtuvo un mayor rendimiento en todas las variables. El uso de PPE ha mostrado ser prometedor en la regeneración del nervio, con resultados favorables cuando se asocia con la grasa como un factor trófico en la regeneración.

PALABRAS CLAVE: Nervio ciático de rata; Regeneración axonal; Tubería de polietileno poroso.

\section{REFERENCES}

Barcelos, A. S.; Rodrigues, A. C.; Silva, M. D. \& Padovani C. R. Inside-out vein graft and inside-out artery graft in rat sciatic nerve repair. Microsurgery, 23(1):66-71, 2003.

Battiston, B. B.; Guizzi, P.; Vigasio, A. \& Brunelli, G. Experimental investigation of cross-nerve transfers relating to repair of brachial plexus avulsion injuries. Microsurgery, 2(11):914, 1990.

Bellamkonda, R. V. Peripheral nerve regeneration: an opinion on channels, scaffolds and anisotropy. Biomaterials, 27(19):3515-8, 2006.

Braga-Silva, J.; Gehlen, D.; Padoin, A. V.; Machado, D. C.; Garicochea, B. \& Costa da Costa, J. Can local supply of bone marrow mononuclear cells improve the outcome from late tubular repair of human median and ulnar nerves? $J$. Hand Surg. Eur. Vol., 33(4):488-93, 2008.

Buchaim, R. L.; Andreo, J. C.; Barraviera, B.; Ferreira Junior, R. S.; Buchaim, D. V.; Rosa Junior, G. M.; de Oliveira, A. L. \& de Castro Rodrigues, A. Effect of low-level laser therapy (LLLT) on peripheral nerve regeneration using fibrin glue derived from snake venom. Injury, 46(4):655-60, 2015.

Da-Silva, C. F. \& Langone, F. Addition of nerve growth factor to the interior of a tubular prosthesis increases sensory neuron regeneration in vivo. Braz. J. Med. Biol. Res., 22(6):691-4, 1989.
Evans, G. R. Peripheral nerve injury: a review and approach to tissue engineered constructs. Anat. Rec., 263(4):396-404, 2001.

Ferrari, F.; De Castro Rodrigues, A.; Malvezzi, C. K.; Dal Pai Silva, M. \& Padovani, C. R. Inside-out vs. standard vein graft to repair a sensory nerve in rats. Anat. Rec., 256(3):227-32, 1999.

Fields, R. D.; Le Beau, J. M.; Longo, F. M. \& Ellisman, M. H. Nerve regeneration through artificial tubular implants. Progr. Neurobiol., 33(2):87-134, 1989.

Georgiou, M.; Golding, J. P.; Loughlin, A. J.; Kingham, P. J. \& Phillips, J. B. Engineered neural tissue with aligned, differentiated adipose-derived stem cells promotes peripheral nerve regeneration across a critical sized defect in rat sciatic nerve. Biomaterials, 37:242-51, 2015.

Grant, G. A.; Goodkin, R. \& Kliot, M. Evaluation and surgical management of peripheral nerve problems. Neurosurgery, 44(4):825-39, 1999.

Hart, A. M.; Terenghi, G. \& Wiberg, M. Neuronal death after peripheral nerve injury and experimental strategies for neuroprotection. Neurol. Res., 30(10):999-1011, 2008.

Hudson, A. R.; Hunter, D.; Kline, D. G. \& Bratton, B. R. Histological studies of experimental interfascicular graft repairs. J. Neurosurg., 51(3):333-40, 1979. 
TOLEDO, G. L.; DA SILVA DE MENEZES, J. D.; DE ALMEIDA NASCIMENTO, J.; ANDREO, J. C.; BUCHAIM, L. R.; SHINOHARA, A. L.; ROSA JUNIOR, G. M. \& DE CASTRO RODRIGUES, A. Ppe tube filled with autologous fat in the repair of peripheral nerve: a new proposal. Int. J. Morphol., 34(3):1151-1157, 2016.

Kakinoki, R.; Nishijima, N.; Ueba, Y.; Oka, M.; Yamamuro, T. \& Nakamura, T. Nerve regeneration over a $25 \mathrm{~mm}$ gap in rat sciatic nerves using tubes containing blood vessels: the possibility of clinical application. Int. Orthop., 21(5):332-6, 1997.

Kljavin, I. J. \& Madison, R. D. PNS axonal regeneration within tubular prostheses: Effects of laminin and collagen matrices on cellular ingrowth. Cell. Mater., 1:17-28, 1991.

Lundborg, G. \& Hanson, H. A. Regeneration of peripheral nerve through a preformed tissue space. Preliminary observations on the reorganization of regenerating nerve fibres and perineurium. Brain Res., 178(2-3):573-6, 1979.

Meek, M. F. \& Coert, J. H. Clinical use of nerve conduits in peripheral-nerve repair: review of the literature. J. Reconstr. Microsurg., 18(2):97-109, 2002.

Mohammadi, R.; Azizi, S.; Delirezh, N.; Hobbenaghi, R. \& Amini, K. Comparison of beneficial effects of undifferentiated cultured bone marrow stromal cells and omental adipose-derived nucleated cell fractions on sciatic nerve regeneration. Muscle Nerve, 43(2):157-63, 2011.

Oliveira, E. F.; Mazzer, N.; Barbieri, C. H. \& DelBel, E. A. The use of a muscle graft to repair a segmentary nerve defect. An experimental study using the sciatic nerve of rats as model. $J$. Neurosci. Methods, 133(1-2):19-26, 2004.

Santiago, L. Y.; Clavijo-Alvarez, J.; Brayfield, C.; Rubin, J. P. \& Marra, K. G. Delivery of adipose-derived precursor cells for peripheral nerve repair. Cell Transplant., 18(2):145-58, 2009.

Sundback, C.; Hadlock, T.; Cheney, M. \& Vacanti, J. Manufacture of porous polymer nerve conduits by a novel low-pressure injection molding process. Biomaterials, 24(5):819-30, 2003.

Sunderland, S. Nervios Periféricos y sus Lesiones. Salvat, Barcelona, 1985.

\author{
Correspondence to: \\ Gustavo Lopes Toledo \\ Mario Ranieri, n. 4-45 \\ Barrio: Shangrilá \\ CEP: $17054-646$ \\ Bauru \\ São Paulo \\ BRAZIL
}

E-mail: gustavobuco@yahoo.com.br

Received:02-03-2015

Accepted:15-07-2016 